\title{
Monitoring Groundwater and Its Suitability for Drinking and Irrigation Purposes in the Sharif Abad Basin, Central Iran
}

\author{
Farzad Mohammadi', Majid Ehteshami², Seyed Ahmad Mirbagheri², Salman Tavassoli1 \\ ${ }^{1}$ Faculty of Civil Engineering, K. N. Toosi University of Technology, Tehran, Iran \\ ${ }^{2}$ Environmental Engineering Department, Faculty of Civil Engineering, K. N. Toosi University of Technology, Tehran, Iran \\ Email: Mohammady.frz@gmail.com
}

How to cite this paper: Mohammadi, F., Ehteshami, M., Mirbagheri, S.A. and Tavassoli, S. (2017) Monitoring Groundwater and Its Suitability for Drinking and Irrigation Purposes in the Sharif Abad Basin, Central Iran. World Journal of Engineering and Technology, 5, 487-506.

https://doi.org/10.4236/wjet.2017.53042

Received: May 19, 2017

Accepted: August 18, 2017

Published: August 21, 2017

Copyright $\odot 2017$ by authors and Scientific Research Publishing Inc. This work is licensed under the Creative Commons Attribution International License (CC BY 4.0).

http://creativecommons.org/licenses/by/4.0/

(c) $\underset{\mathrm{EY}}{0}$ Open Access

\begin{abstract}
The purpose of this study was to analyze the quality and quantity of groundwater in Sharif Abad Basin, located in Central Iran. The analysis of data collected from 24 observation wells indicated that the mean water table has plummeted about $0.896 \mathrm{~m} /$ year during 19 years between 1993 and 2013 due to illegal groundwater pumping, which is the main cause of groundwater quality deterioration in this area. Seventeen samples were collected and analyzed to study physicochemical characteristics of groundwater such as pH, Hardness, Chloride (Cl), Electrical Conductivity (EC) and Total Dissolved Solids (TDS) values. The results were compared to drinking water quality standard published by World Health Organization (WHO) and it was concluded that none of the water samples was potable. The spatial distribution of anions and cations followed an increasing pattern eastwards towards the Salt Lake. The analysis of Hydrochemical facies of groundwater using Piper diagram indicated that the major type of groundwater in this basin is $\mathrm{Na}-\mathrm{Cl}$, which is mainly different from common type of fresh water in Iran $\left(\mathrm{Ca}-\mathrm{HCO}_{3}\right)$. Suitability of groundwater for irrigation purpose was assessed using Wilcox diagram and it was shown that all the water samples in 2013 belonged to C4S4 category, meaning they were not suitable for irrigation either. According to the ratio of chloride-bicarbonate, $100 \%$ of the samples were contaminated by saltwater intrusion. Also, the sodium-chloride ratio indicated that almost $60 \%$ of samples were contaminated by Halite solution. The presence of this solution proves the presence of salt domes in this area.
\end{abstract}

\section{Keywords}

Groundwater Quality, Wilcox Diagram, Piper Diagram, Salinity, Sharif Abad Basin 


\section{Introduction}

One third of the Earth's land surface is covered by arid and semi-arid areas. Water shortage is the most critical issue in these regions. Groundwater pollution is an environmental, social and political issue worldwide, so it is essential to study its quality to manage and protect this precious resource. Iran, in which water shortage and water quality deterioration are related to each other, is one of 27 countries predicted to face water scarcity crises between 2007 and 2025 [1] [2]. Sharif Abad basin, with an average height of $850 \mathrm{~m}$ from sea level, which includes $441 \mathrm{~km}^{2}$ of area, is located in Iran Central Desert between $33^{\circ} 45^{\prime}$ and $34^{\circ} 23^{\prime}$ latitude, and $51^{\circ} 05^{\prime}$ and $51^{\circ} 54^{\prime}$ longitude. This area is extended in a west-east direction so that it is restricted to Qom basin from south and Saveh from west and reaches to Salt Lake from the east. This basin has a dry climate and the main river of the area was Qom River which was dried out in 1994 due to construction of "15 Khordad" dam, so groundwater is the sole source of water supply for urban, irrigation and industrial uses in this area. Population growth and consequently the rise in water consumption in upstream areas, not allocating water share from Saveh Dam to this basin, development of numerous projects that has caused over pumping groundwater and also being in the vicinity of Salt Lake are the main threats for quantity and quality of the Sharif Abad aquifer. Many researchers have evaluated and analyzed the quantity and quality of the groundwater worldwide [3] [4] [5] [6].

Psychoyou et al. measured values of EC, $\mathrm{pH}$, Eh and also main anions and cations twice, at the end of rainy and dry periods in the region of Marathon in Attica, in a network of 56 observation boreholes. Results showed that, high pumping rates leading to saltwater intrusion and consequently high salt concentration, severely escalated groundwater quality deterioration, particularly in areas close to the sea [7].

Yidana et al. carried out a multivariate and spatial analysis of groundwater in the Keta strip of the Keta basin. Major causes of groundwater salinity were detected as mineral weathering and seawater intrusion. Effect of saltwater intrusion on SAR was also analyzed. 51.5\% of samples were found of a good quality for drinking, while $38.5 \%$ of them had fair and $10 \%$ had marginal quality [8].

Stamatis et al. did a research on Oropos-Kalamos basin in Greece to define the effects of geology, lithology and human activities on groundwater quality. In this investigation, gathered data from 25 sampling sites were analyzed. Employing Durov diagram, five different groundwater facies recognized in this aquifer: $\mathrm{Ca}-\mathrm{HCO}_{3}, \mathrm{Mg}-\mathrm{HCO}_{3}, \mathrm{Na}-\mathrm{Cl}, \mathrm{Mg}-\mathrm{Cl}$ and $\mathrm{Ca}-\mathrm{Cl}$. Also, water quality for drinking and irrigation purposes was evaluated in this study [9].

Kshetrimayum and Bajpai studied the groundwater of Makanda river basin to assess the groundwater quality for irrigation use. Hydrochemical analysis based on variety of parameters was done. Groundwater quality in this aquifer has been found appropriate for irrigation. Dominant hydrochemical facies of the groundwater in this area was which showed that it has seeped through sandstone and limestone rocks [10]. 
Al-Ahmadi surveyed groundwater quality of Wadi Saayyah in Saudi Arabia, analysis was carried out on 42 groundwater samples. Results indicated that the major ions dominance order were as follows: $\mathrm{Ca}>\mathrm{Na}>\mathrm{Mg}>\mathrm{K}$ and $\mathrm{Cl}>\mathrm{SO}_{4}>$ $\mathrm{HCO}_{3}>\mathrm{NO}_{3}$. The influential groundwater types were $\mathrm{Ca}-\mathrm{Cl}$, and mixed $\mathrm{Ca}-\mathrm{Mg}-$ Cl. According to Gibb's diagram, rock weathering and evaporation are the prominent process affecting the groundwater quality [11].

Pazand and Javanshir evaluated groundwater quality in Mohammad Abad area in Iran. This research showed that groundwater type is $\mathrm{Na-Cl}$ and it is alkaline. Study indicated that many water samples were suitable for drinking according to WHO criteria. Statistical analysis showed TDS strong correlation with $\mathrm{Cl}$ and $\mathrm{Na}[1]$.

Since no study has been conducted in this area for groundwater resources, the objectives of this paper are to assess the quantity and quality of the groundwater for different uses and find the main sources of the pollution. In this research, the fluctuation of groundwater level over past decades is considered, furthermore, the effect of this phenomenon on groundwater quality of the study area is defined in the last year (2013) and potential causes of contamination are examined. Suitability of groundwater for drinking and irrigation purposes is discussed as well.

\section{Materials and Methods}

In this study, evaluation of groundwater quantity and quality were conducted using data obtained from 17 sampling wells and 24 observation wells. The location of study area and sampling wells which are recorded in Universal Transverse Mercator (UTM) coordinate system are shown in Figure 1 and Figure 2

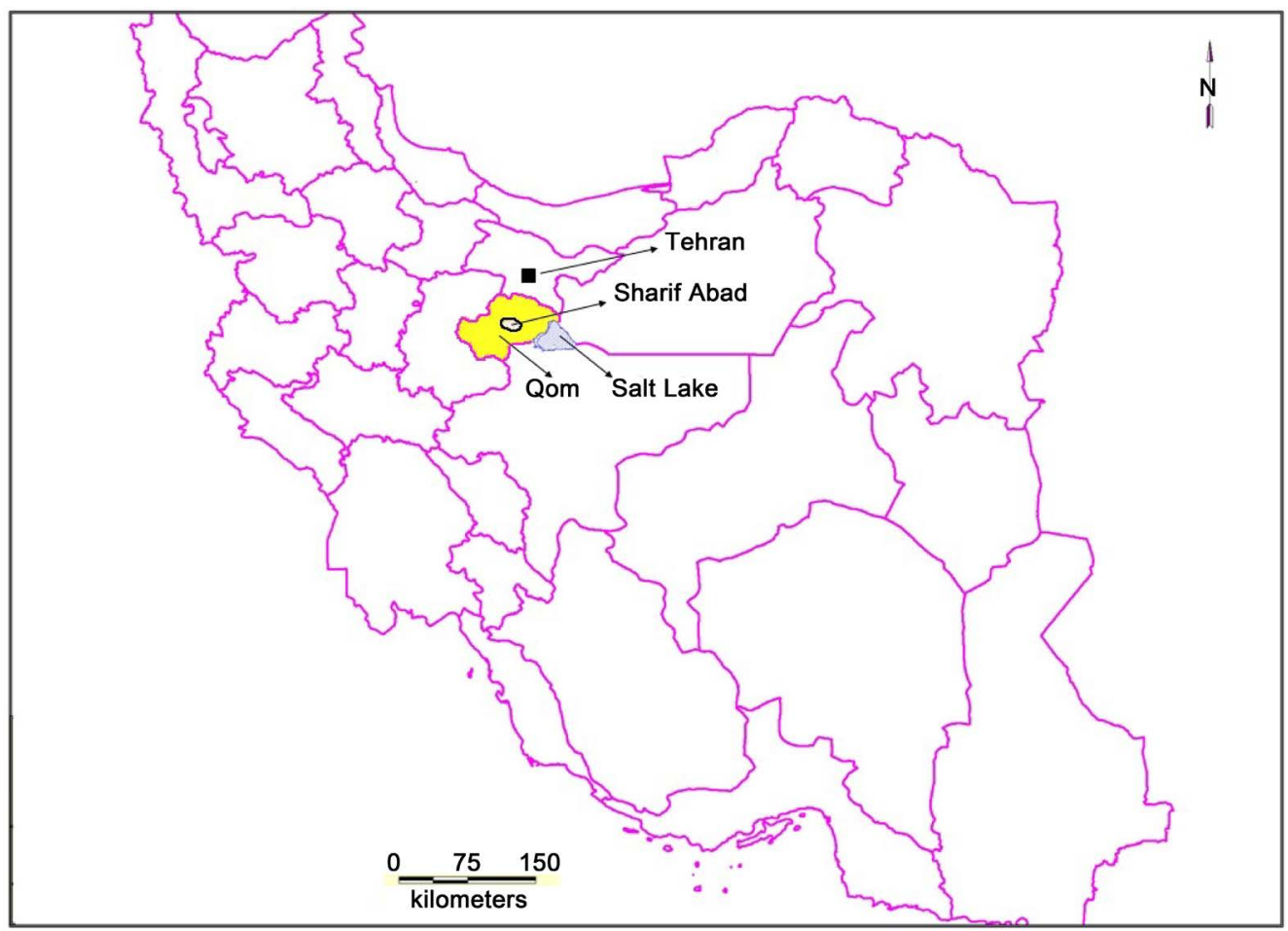

Figure 1. Sharif Abad basin location in Iran. 


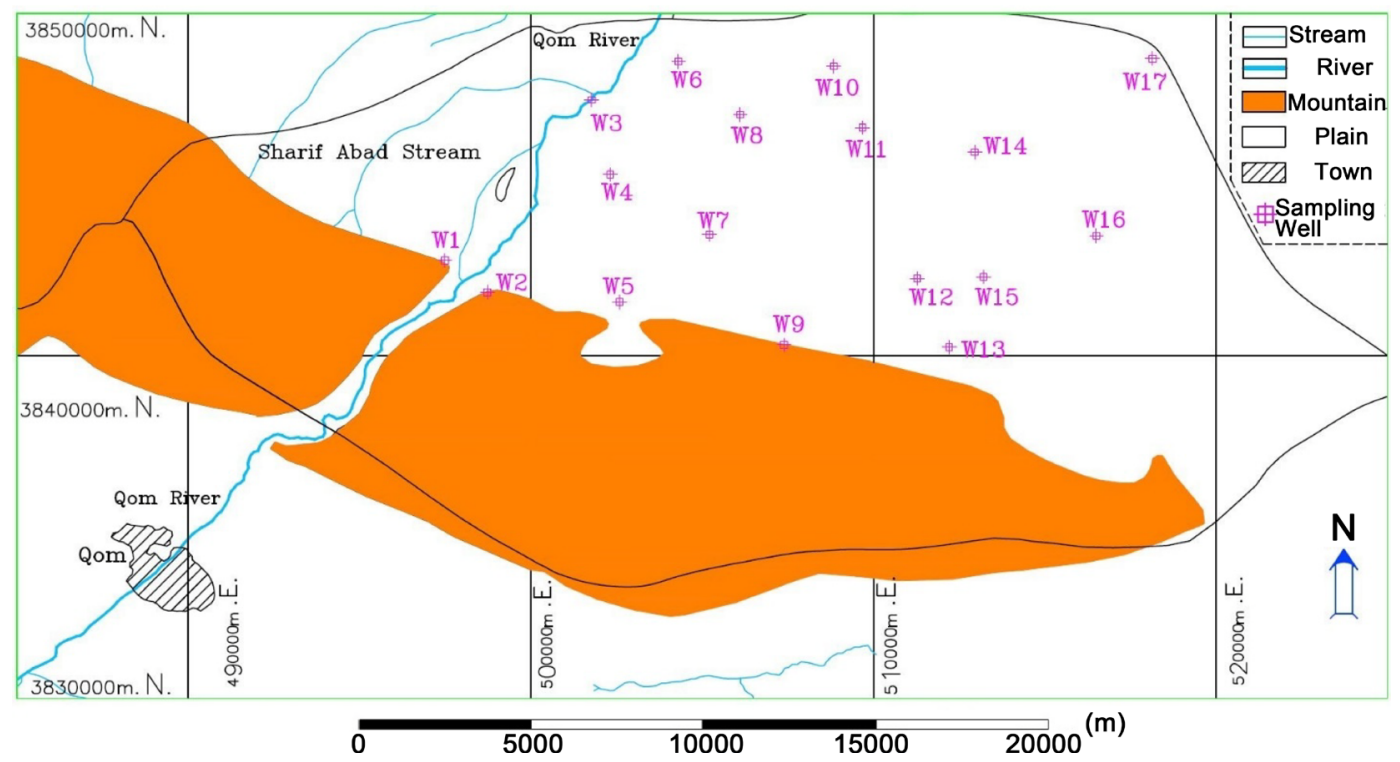

Figure 2. Location of sampling wells within the Sharif Abad basin.

Table 1. Methods used for the analysis of quality parameters.

\begin{tabular}{cc}
\hline Parameters & Method used \\
\hline $\mathrm{PH}$ & 4500-H B AWWA/APHA, 1998 PH meter \\
$\mathrm{EC}$ & 2510-B AWWA/APHA, 1998 EC meter \\
TDS & 2540-C AWWA/APHA, 1998 gravimetric method \\
$\mathrm{Ca}, \mathrm{Na}$ and $\mathrm{K}$ & 3111-B AWWA/APHA, 1998 flame photometry \\
$\mathrm{Mg}$ & 3111-B AWWA/APHA, 1998 flame atomic absorption spectrometry \\
$\mathrm{HCO}_{3}, \mathrm{CO}_{3}, \mathrm{Cl}$ and $\mathrm{SO}_{4}$ & 4500-E AWWA/APHA, 1998 spectrophotometer
\end{tabular}

respectively.

Groundwater level data, during 1993-2013, and also groundwater quality data during 2004-2013, which included total number of 153 water samples, were collected annually to determine the groundwater level and suitability of groundwater for different uses. All water samples' physiochemical parameters, including pH, Total Dissolved Solid (TDS), Electrical Conductivity (EC), Total Hardness $(\mathrm{TH})$, major anions $\left(\mathrm{HCO}_{3}, \mathrm{CO}_{3}, \mathrm{Cl}, \mathrm{SO}_{4}\right)$ and major cations (Ca, $\mathrm{Mg}, \mathrm{Na}$ and $\mathrm{K}$ ) were analyzed in accordance with APHA standards (Table 1) [12]. These data are used to monitor how groundwater level decreased during 1993-2013. The origin of groundwater contamination is determined based on some indices and theories such as chloride-bicarbonate ratio, sodium-chloride ratio and Chebotarev sequence [13]. Moreover the suitability of groundwater for drinking and irrigation purposes are defined through standard limits for drinking water by WHO and Wilcox diagram respectively. Piper diagram is implemented to define groundwater facies of this basin as well.

\section{Results and Discussion}

\subsection{Groundwater Depletion}

Groundwater elevation data were collected from 24 wells between 1993 and 
2013. Figure 3 illustrates the average annual groundwater table fluctuation, the average groundwater table fluctuation in October and the average groundwater table fluctuation in September. As can be seen there has been a drastic drop in groundwater level during 1993 and 2013. Groundwater level has declined nearly 17 meters during past 19 years, which means $0.896 \mathrm{~m} /$ year. Many factors, such as low precipitation rate, drought, increasing demand and therefore the rise in the number of pumping wells and also pumping rates caused this drop. Controlling pumping rates and also allocating the water share from upstream dams during 2005 to 2009 tempered the decrease of groundwater table; however during last four years by suspending those policies and also ongoing drought, decrease in groundwater level has persisted with higher slope. Analysis of data indicated that decrease in water table was not uniform throughout the region and depletion in area with higher pumping rates and/or more number of pumping wells was higher, as expected.

\subsection{Groundwater Quality Deterioration}

In order to assess the groundwater quality in the study area, acquired data from 17 sampling wells during 2004 and 2013, were analyzed. According to the previous study in other regions of central Iran, major cause of groundwater quality decline is salinity [14]. Diagram of average annual changes in available parameters are drawn. Diagrams indicate that most of the concentrations increased in last 9 years.

Hydrochemical facies and suitability of samples for irrigation purpose, in 2013, were established using Piper and Wilcox diagrams, respectively. In addition, different water quality parameters including $\mathrm{pH}$, TDS, $\mathrm{EC}, \mathrm{TH}, \mathrm{Cl}, \mathrm{Na}, \mathrm{SO}_{4}$, etc. concentration values of samples in 2013, were measured (Table 2) and compared with WHO guidelines to evaluate the suitability of groundwater for

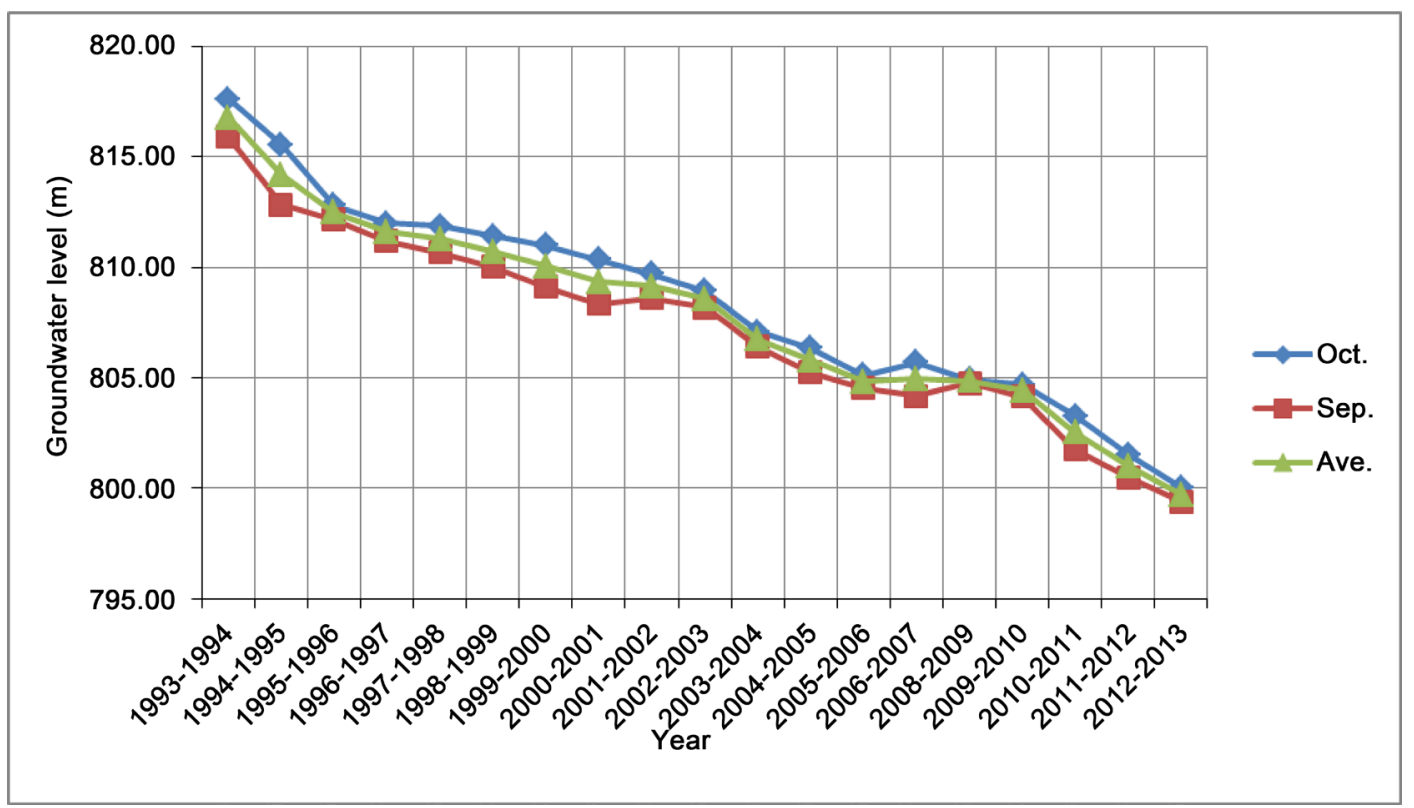

Figure 3. Elevation of water table within the Sharif Abad basin, 1993-2013. 
Table 2. Hydrochemical parameters for selected water samples in the Sharif Abad Basin (2013).

\begin{tabular}{|c|c|c|c|c|c|c|c|c|c|c|c|c|c|c|}
\hline \multirow{2}{*}{$\begin{array}{l}\text { Sampling } \\
\text { Well }\end{array}$} & \multicolumn{2}{|c|}{$\begin{array}{l}\text { Geographical Coordinate } \\
\text { (UTM Zone: } 39 \text { S) }\end{array}$} & \multirow{2}{*}{$\mathrm{PH}$} & \multirow{2}{*}{$\begin{array}{c}\mathrm{EC} \\
(\mu \mathrm{S} / \mathrm{cm})\end{array}$} & \multirow{2}{*}{$\begin{array}{c}\text { TDS } \\
(\mathrm{mg} / \mathrm{L})\end{array}$} & \multirow{2}{*}{$\begin{array}{c}\mathrm{TH} \\
\left(\mathrm{mg} / \mathrm{L} \text { as } \mathrm{CaCO}_{3}\right)\end{array}$} & \multicolumn{4}{|c|}{ Cations (meq/L) } & \multicolumn{4}{|c|}{ Anions $(\mathrm{meq} / \mathrm{L})$} \\
\hline & $\mathrm{X}$ & $\mathrm{Y}$ & & & & & $\mathrm{Ca}$ & K & $\mathrm{Na}$ & $\mathrm{Mg}$ & $\mathrm{HCO}_{3}$ & $\mathrm{CO}_{3}$ & $\mathrm{Cl}$ & $\mathrm{SO}_{4}$ \\
\hline W1 & 497,492 & $3,842,792$ & 7.59 & 6040 & 4065 & 1076 & 13.50 & 0.25 & 45.22 & 8.02 & 3.51 & 0 & 44.80 & 18.40 \\
\hline W2 & 498,728 & $3,841,862$ & 7.66 & 8448 & 5447 & 1412 & 17.50 & 0.30 & 58.84 & 10.75 & 3.50 & 0 & 57.30 & 27.84 \\
\hline W3 & 501,770 & $3,847,475$ & 7.76 & 14,850 & 8902 & 1816 & 16.20 & 0.27 & 112.10 & 20.11 & 3.50 & 0 & 110.10 & 31.84 \\
\hline W4 & 502,314 & $3,845,303$ & 7.22 & 10250 & 6901 & 2100 & 24.50 & 0.26 & 71.50 & 17.50 & 2.20 & 0 & 75.10 & 29.51 \\
\hline W5 & 502,584 & $3,841,574$ & 7.57 & 9293 & 5739 & 1451 & 15.80 & 0.23 & 60.33 & 13.21 & 5.00 & 0 & 59.10 & 25.48 \\
\hline W6 & 504,309 & $3,848,591$ & 7.33 & 9336 & 6172 & 1516 & 20.50 & 0.32 & 72.90 & 9.82 & 3.10 & 0 & 77.10 & 17.55 \\
\hline W7 & 505,207 & $3,843,544$ & 7.43 & 9940 & 6154 & 1232 & 12.50 & 0.25 & 73.50 & 12.14 & 2.70 & 0.05 & 77.20 & 20.65 \\
\hline W8 & 506,110 & $3,847,040$ & 7.60 & 14,001 & 8671 & 2300 & 24.50 & 0.38 & 98.78 & 21.50 & 3.55 & 0.05 & 99.80 & 45.86 \\
\hline W9 & 507,389 & $3,840,329$ & 7.33 & 9501 & 5946 & 1333 & 14.50 & 0.39 & 64.21 & 12.15 & 2.30 & 0 & 62.20 & 34.11 \\
\hline W10 & 508,837 & $3,848,455$ & 7.89 & 13,500 & 8896 & 2355 & 17.70 & 0.34 & 100.10 & 29.40 & 2.33 & 0 & 97.40 & 47.11 \\
\hline W11 & 509,681 & $3,846,659$ & 7.64 & 11,682 & 7992 & 2095 & 25.20 & 0.25 & 84.11 & 16.70 & 2.10 & 0 & 84.00 & 44.75 \\
\hline W12 & 511,276 & $3,842,260$ & 7.46 & 10,870 & 6760 & 1780 & 24.10 & 0.37 & 79.10 & 11.50 & 2.10 & 0 & 80.10 & 34.50 \\
\hline W13 & 512,208 & $3,840,262$ & 7.52 & 10,645 & 6561 & 1637 & 19.80 & 0.3 & 75.89 & 12.94 & 1.54 & 0.05 & 74.10 & 28.90 \\
\hline W14 & 512,958 & $3,845,946$ & 7.60 & 12,850 & 8239 & 2136 & 26.50 & 0.33 & 90.30 & 16.25 & 2.10 & 0.05 & 94.10 & 46.99 \\
\hline W15 & 513,213 & $3,842,308$ & 7.90 & 12,500 & 7492 & 2335 & 24.50 & 0.35 & 83.26 & 22.20 & 2.04 & 0 & 88.50 & 39.81 \\
\hline W16 & 516,502 & $3,843,508$ & 7.46 & 16,550 & 9997 & 2390 & 28.10 & 0.22 & 105.14 & 19.72 & 2.21 & 0.05 & 112.70 & 48.65 \\
\hline W17 & 518,138 & $3,848,681$ & 7.73 & 21,050 & 14,445 & 3430 & 40.10 & 0.5 & 150.20 & 28.50 & 2.00 & 0.05 & 161.00 & 69.50 \\
\hline
\end{tabular}

Table 3. Groundwater quality parameters in the Sharif Abad Basin during 2013.

\begin{tabular}{ccccc} 
Water Quality Parameters & WHO Standard Value & Experimental Value (Range) & Mean Value $(\mathrm{n}=17)$ & Description \\
\hline $\mathrm{PH}$ & $6.5-8.5$ & $7.22-7.9$ & 7.57 & OK For All Samples \\
$\mathrm{EC}(\mu \mathrm{S} / \mathrm{cm})$ & 1400 & $6040-21,050$ & 11842 & Too much For All samples \\
$\mathrm{TDS}(\mathrm{mg} / \mathrm{L})$ & 1000 & $4065-14,445$ & 7552 & Too much For All samples \\
$\mathrm{CaH}(\mathrm{mg} / \mathrm{L})$ & 100 & $250-802$ & 429.9 & Too much For All samples \\
$\mathrm{MgH}(\mathrm{mg} / \mathrm{L})$ & 150 & $97.4-346.27$ & 201.8 & Too much For $65 \%$ of samples \\
$\mathrm{TH}(\mathrm{mg} / \mathrm{L})$ & 500 & $1076-3430$ & 1905 & Too much For All samples \\
$\mathrm{Cl}(\mathrm{mg} / \mathrm{L})$ & 250 & $1588.16-5707.45$ & 3033.1 & Too much For All samples \\
$\mathrm{Na}(\mathrm{mg} / \mathrm{L})$ & 200 & $1040.06-3454.6$ & 1928.6 & Too much For All samples \\
$\mathrm{K}(\mathrm{mg} / \mathrm{L})$ & - & $8.6-19.55$ & 12.2 & No Comparison exists \\
$\mathrm{SO}(\mathrm{mg} / \mathrm{L})$ & 250 & $842.52-3336$ & 1726.4 & Too much For All samples \\
\hline
\end{tabular}

drinking and public health (Table 3). According to Table 3, water quality was not suitable for drinking in any part of the basin. 


\subsubsection{The pH Value}

Although WHO does not suggest any health-based guideline value for $\mathrm{pH}$, concerning aesthetic aspect, a value range of $6.5-8.5$ is established for $\mathrm{pH}$. The $\mathrm{pH}$ values of groundwater samples in the study area showed that this parameter varied between 7.22 and 7.9 in 2013, which means they were all in the permissible range. All samples had values more than 7 , indicating slightly alkaline nature of the samples.

$\mathrm{pH}$ role as an operational water quality parameter is indisputable fact. Disinfection of water with chloride, which is one of the stages in water treatment procedure, needs the $\mathrm{pH}$ value to be less than 8 to be satisfactory, it even may be inconclusive in $\mathrm{pH}$ values above 9. Moreover, to protect the water distribution system, including mains and pipes, from corrosion, the $\mathrm{pH}$ has to be managed. Otherwise, corrosion may cause contamination and impact on taste, smell and appearance of drinking water. High $\mathrm{pH}$ value in water causes faster scale formations in water heating equipment [15] [16]. On the other hand, low $\mathrm{pH}$ in groundwater leads to acidic condition which causes dissolution of insoluble carbonates in soil and limestone formation in water. This phenomenon results in the increase of impurities such as sulfates, chlorides and silicates concentration in groundwater [4].

\subsubsection{The EC Value}

Dissolution of organic substances including cations such as sodium, magnesium, calcium, iron, and aluminum, and anions like chloride, nitrate, sulfate, and phosphate has an influence on the ability of water to pass the electrical current, which is called Electrical Conductivity (EC). Electrical conductivity of groundwater could be affected by geology of the basin and the bedrock [17]. The dominant water quality guideline for crop yield is the peril of water salinity which is measured by EC. High EC value irrigation water causes physiological drought. It means that plants root are unable to compete with ions for water in soil. By increasing the EC available water to crops decreases. This phenomenon has an adverse effect on crop yield [18].

In Sharif Abad basin EC values of water samples in 2013 varied from 6040 to $21,050 \mu \mathrm{S} / \mathrm{cm}$, which according to WHO standard is significantly higher than maximum permissible value of $1400 \mu \mathrm{S} / \mathrm{cm}$ for drinking water [15]. Spatial distribution of EC throughout the study area is shown in Figure 4 indicating higher concentration of total salt in the eastern part, near the Salt Lake. It can be concluded from Figure 4 that the dominant reason for EC increase in this basin is saltwater intrusion from the Salt Lake. Moreover, annual average of EC values from 2004 to 2013 shows a continuous growth (Figure 5).

\subsubsection{The Chloride Value}

Presence of chloride is natural in different kinds of water. $\mathrm{Cl}$ (Chloride ion) is the major natural form of this element which is highly stable in groundwater [3] [6] [16]. Both natural sources such as precipitation, evaporates, dissolution and weathering the halite and anthropogenic sources like domestic and industrial 


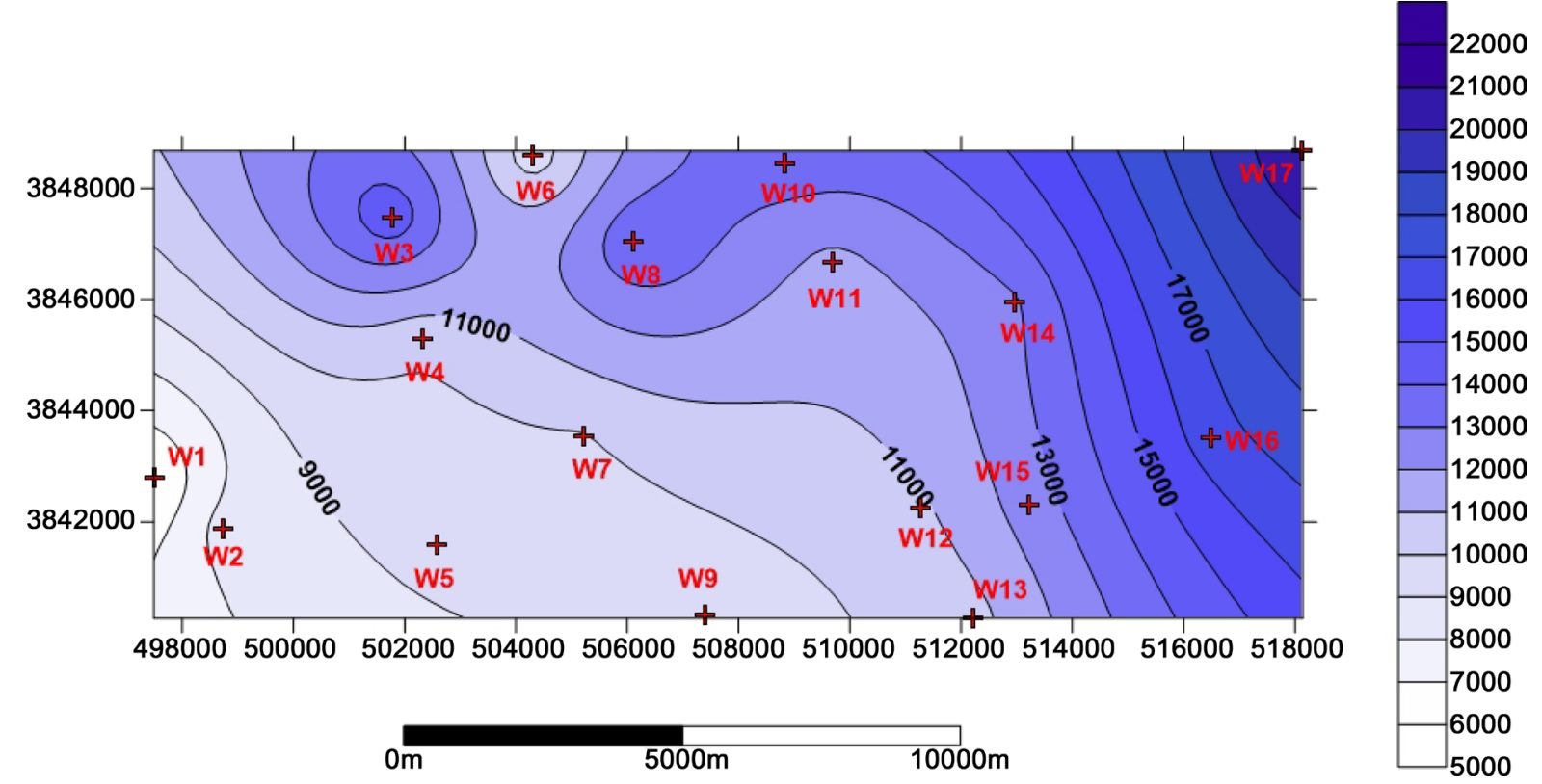

Figure 4. EC distribution of sampling wells.

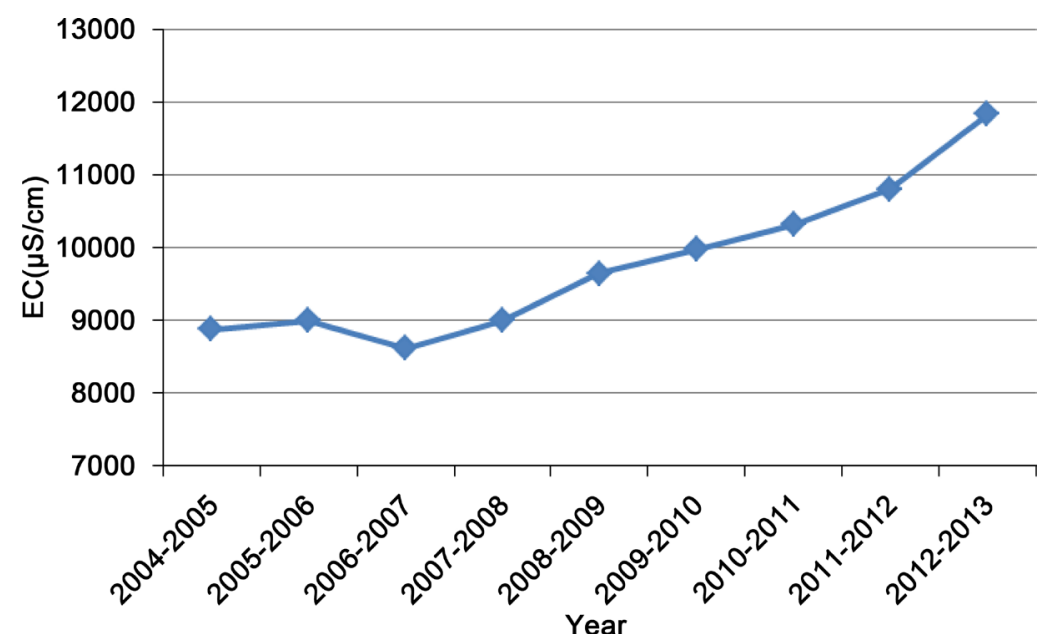

Figure 5. Average annual of EC during 2004-2013.

effluent, urban runoff, septic, fertilizer, industrial and animal waste and also saline intrusion can be the origin of chloride in groundwater [15] [19]-[24]. High concentrations of chloride may lead to escalate the corrosion of distribution system which increases the metal concentration in drinking water. It also can turn the water taste to salty and causes laxative conditions for people not adapted to it [15] [25]. WHO standard for chloride is based on taste. Concentration exceeding $250 \mathrm{mg} / \mathrm{L}$ may be detectable and concentration more than $600 \mathrm{mg} / \mathrm{L}$ would have a noticeable impact on the suitability of water for drinking purpose.

In 2013, chloride concentration values in water samples of the study area varied between 1588 and $5707 \mathrm{mg} / \mathrm{L}$, indicating that the water samples are highly salty. Chloride concentration in all samples was dramatically higher than prescribed WHO limit. Chloride distribution in 2013 (Figure 6) implies that $\mathrm{Cl}$ concentration is higher in eastern part of the study area that is closer to Salt 


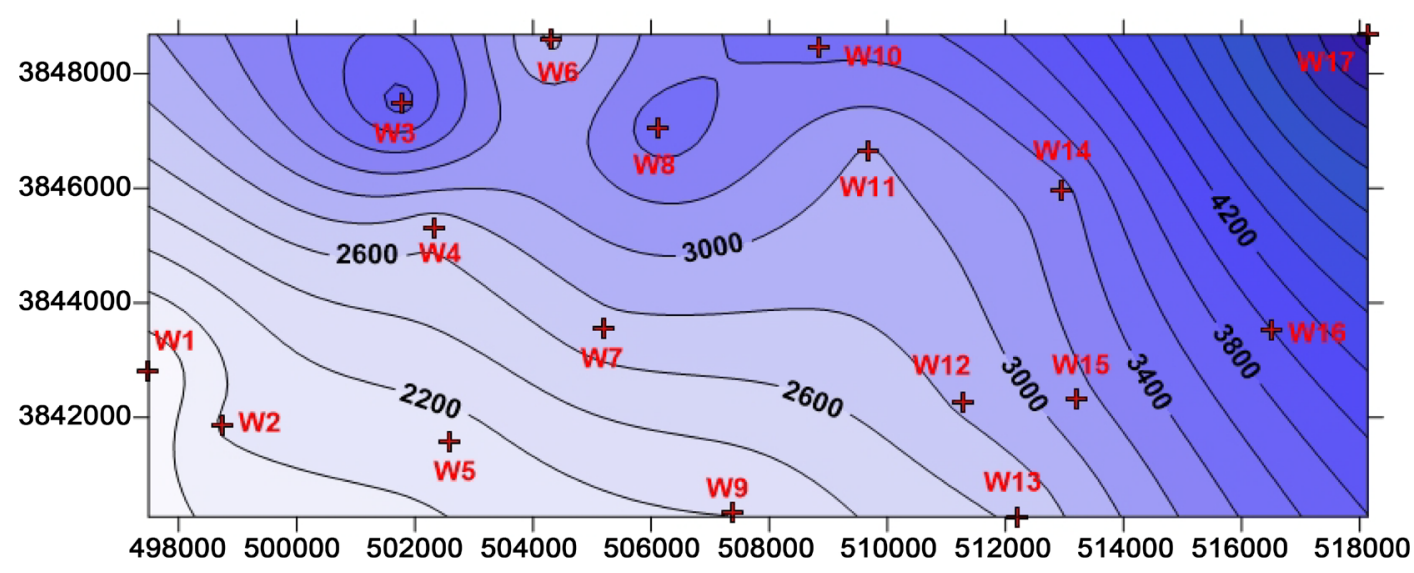

498000500000502000504000506000508000510000512000514000516000518000

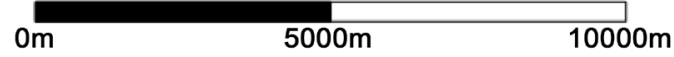

Figure 6. Chloride distribution of sampling wells.

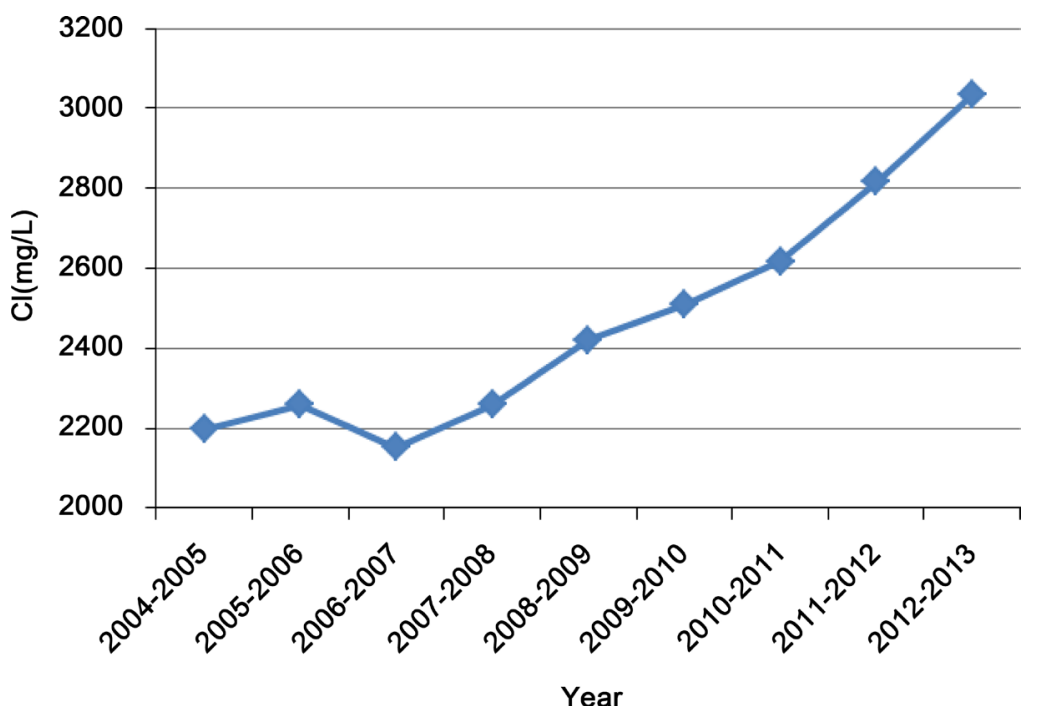

Figure 7. Average annual of Chloride during 2004-2013.

Lake. Two dominating phenomena causing high chloride concentration can be saltwater intrusion from east, where Salt Lake is located, and salt dome in northern part of the study area (around W3 and W8). Diagram of average annual chloride concentration values shows a continuous increase from 2004 to 2013 (Figure 7).

\subsubsection{The Total Dissolved Solid (TDS) Value}

TDS consists of mainly inorganic salts including calcium, magnesium, potassium, sodium, bicarbonates, chlorides and sulfates and a slight amount of organic substances which are dissolved in water. The origins of TDS include natural sources and also industrial discharges, urban runoff, sewage, fertilizers, road run off (containing salts used for road deicing) [15]. There is always a relationship 
between TDS and the electrical conductivity of water [26] [27]. High concentration of TDS can have an unfavorable effect on people and makes the water unpalatable. Too high or too low TDS concentration can lower the effectiveness of wastewater treatment plants and industrial processes that use raw water [28]. The concentration more than $1000 \mathrm{mg} / \mathrm{L}$ for TDS in water can cause scale build-up in distribution system, heaters, boilers and household appliances. According to WHO there are no reliable evidence on effects of drinking water with high TDS concentration on human health, so no health-based guideline was suggested. However, based on taste consideration, maximum concentration of $1000 \mathrm{mg} / \mathrm{L}$ was proposed for TDS [15].

In this study area, the TDS values of samples were in the range of 4065 $14,445 \mathrm{mg} / \mathrm{L}$ in 2013 . None of water samples were permissible for drinking or even irrigation purposes. The TDS distribution of groundwater in 2013 and also average annual of groundwater TDS concentration in this study area during 2004 to 2013 is shown in Figure 8 and Figure 9 respectively.

Categorization of groundwater based on their hydrochemical properties is requisite to establish the suitability of it. This classification is presented in Table 4 [29].

\subsubsection{The Hardness Value (TH)}

Hardness is mostly caused by dissolution of calcium and magnesium and also other metals. Since hard water hinders home laundry and washing by reducing the effect of soap and synthetic detergent and also can result in scale formation in boilers and industrial equipment, it is an important matter for industrial and domestic water users. On the other hand, hardness less than $100 \mathrm{mg} / \mathrm{L}$ declines the water buffering capacity and causes corrosion in water pipes [15] [30].

Drinking very hard water for long might give rise to heart disease and

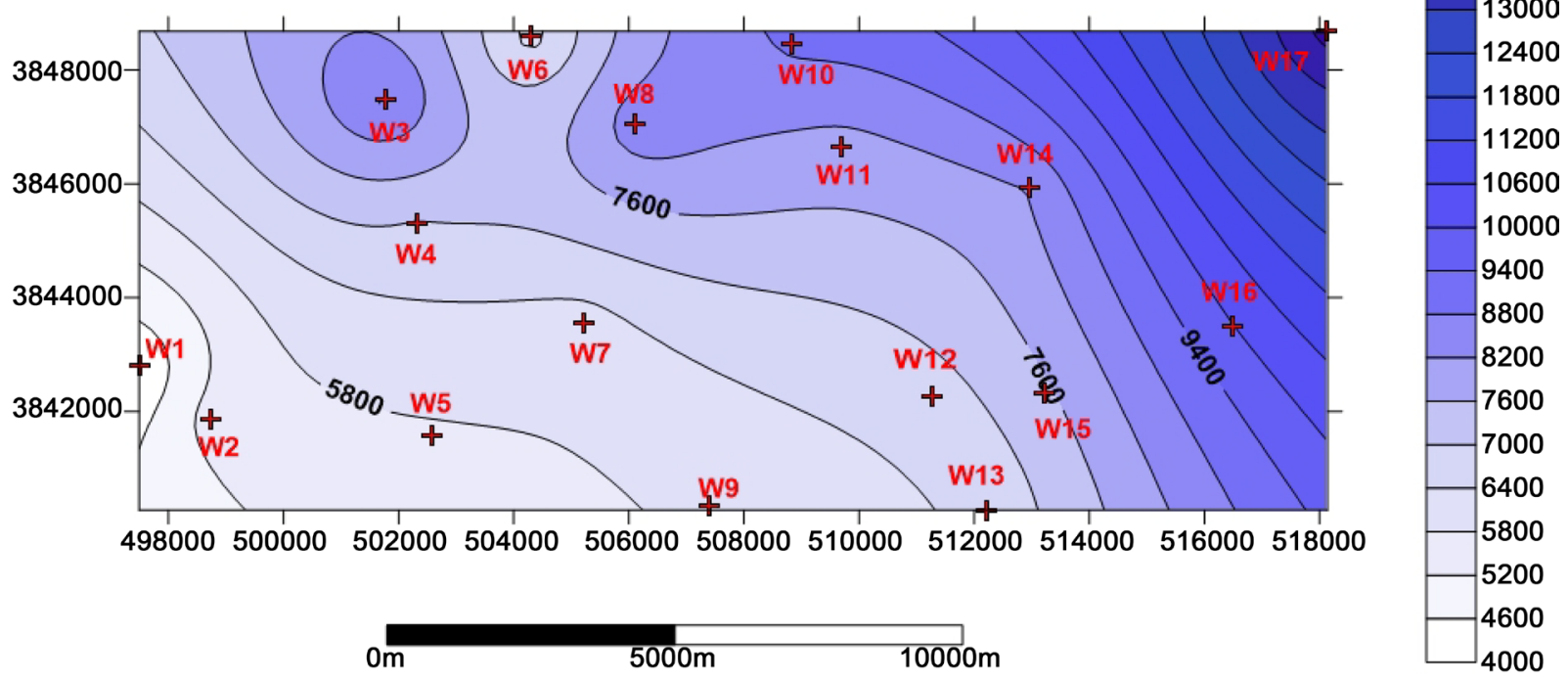

Figure 8. TDS distribution of sampling wells. 


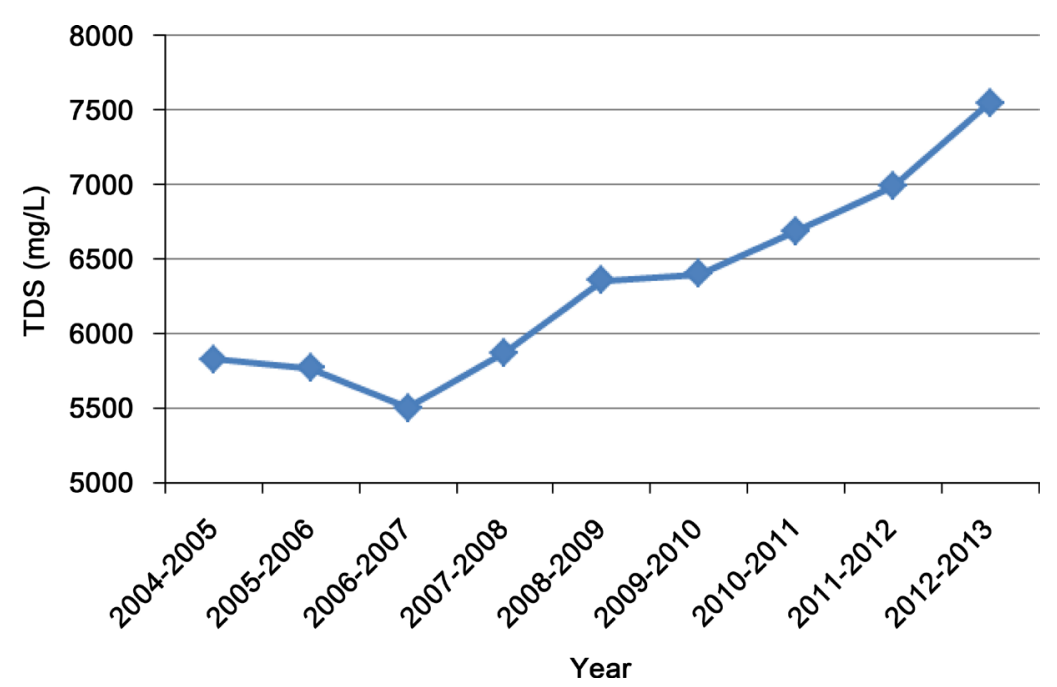

Figure 9. Average annual of TDS during 2004-2013.

Table 4. Salinity scale for groundwater.

\begin{tabular}{ccc}
\hline TDS $(\mathrm{mg} / \mathrm{L})$ & Description & Number of samples \\
\hline$<500$ & Desirable for drinking & 0 \\
$500-1000$ & Permissible for drinking & 0 \\
$1000-3000$ & Useful for irrigation & 0 \\
$>3000$ & Unfit for drinking and irrigation & 17 \\
\hline
\end{tabular}

Table 5. Hardness scale for drinking water.

\begin{tabular}{ccc}
\hline $\mathrm{TH}\left(\mathrm{mg} / \mathrm{L}\right.$ as $\left.\mathrm{CaCO}_{3}\right)$ & Description & Number of Samples \\
\hline $0-60$ & Soft & 0 \\
$61-120$ & Moderately Hard & 0 \\
$121-180$ & Hard & 17 \\
More than 180 & Very hard & 0 \\
\hline
\end{tabular}

urolithiasis [31]. However, there is some evidence that very soft water may cause an unfavorable effect on mineral balance of human system [15].

Concerning the adequacy of water for domestic use the maximum allowable level of $10 \mathrm{meq} / \mathrm{L}$ (500 $\mathrm{mg}$ calcium carbonate/L) in drinking water, is proposed by WHO. Nevertheless, suitability of TH level in water may differ in different communities, for example in some countries hardness level exceeding $500 \mathrm{mg} / \mathrm{L}$ is accepted by consumers in some cases [15]. Following formula is used in this study to calculate $\mathrm{TH}$ of the groundwater [32].

$$
\mathrm{TH}=(\mathrm{Ca}+\mathrm{Mg}) * 50
$$

where $\mathrm{TH}$ is reported in $\mathrm{mg} / \mathrm{L}$ as $\mathrm{CaCO}_{3}$ and $\mathrm{Ca}$ and $\mathrm{Mg}$ in meq/L.

In this study area, the TH values of water samples were in the range of 1076 $3430 \mathrm{mg} / \mathrm{L}$ in 2013, signifying that all the water samples were in the "very hard" category. Water samples were classified based on general scale for hardness in Table 5 [30]. 


\subsubsection{The Sodium Value}

Sodium is the sixth ample element on earth and broadly exists in soil, plants, water, and food [33]. Sodium is also one of the main cations that naturally exist in fresh water. However, $\mathrm{Na}$ concentration is usually lower than $\mathrm{Ca}$ and $\mathrm{Mg}$ [16]. Sodium may discharge to groundwater through road deicing chemicals, water treatment chemicals, domestic water softeners and sewage effluents [33]. Since there is no evidence of contribution of sodium presence in drinking water to hypertension occurrence, no health based guideline is recommended by WHO. Nonetheless, based on taste adequacy, maximum limit of $200 \mathrm{mg} / \mathrm{L}$ is proposed [15].

The sodium concentration in water samples of the study area were in the range of $1040-3827 \mathrm{mg} / \mathrm{L}$ in 2013. All the concentration in water samples exceeded the standard value suggested by WHO. The average concentration of sodium in water samples was relatively higher than $\mathrm{Ca}$ and $\mathrm{Mg}$ (Table 2). This may be caused by geology of the study area, presence of the salt domes, and/or saltwater intrusion from Salt Lake. The growth of annual average of sodium values of groundwater for this basin during past decade is shown in Figure 10.

\subsubsection{The Sulfate Value}

Naturally, sulfate exists in drinking water [34]. Highest concentration of sulfates typically happens in groundwater and originates from natural resources. They also may enter the groundwater through industrial waste and atmospheric deposition. Sulfate level more than $250 \mathrm{mg} / \mathrm{L}$ results in conspicuous taste and corrosion of distribution system [15]. High level of sulfate may also contribute to diarrhea, especially when the concentration changes abruptly from low to high in drinking water. This may cause gastrointestinal irritation to the human system [32] [34].

According to WHO sulfate concentration higher than $400 \mathrm{mg} / \mathrm{L}$ would considerably impact the potability of water. Sulfate values of samples were in the range of $883-3336 \mathrm{mg} / \mathrm{L}$ in 2013. Comparing with WHO prescribed standard,

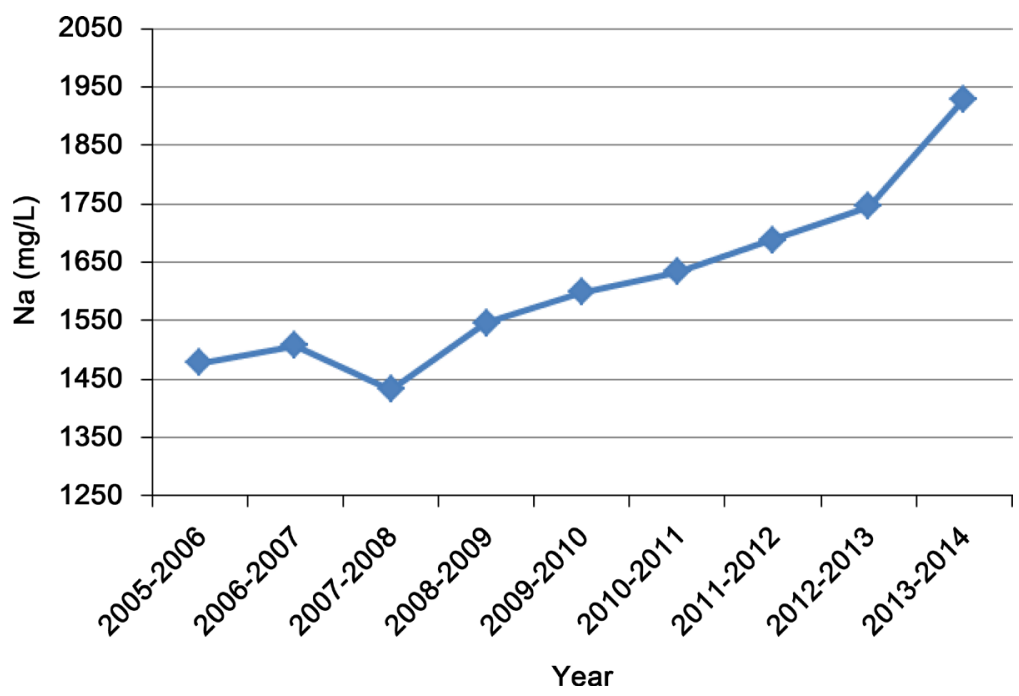

Figure 10. Average annual of sodium during 2004-2013. 
all the samples were significantly out of standard range.

\subsection{Hydrochemical Facies}

Hydrochemical facies of groundwater are mainly affected by rocks and soil of the aquifer [5]. Residence time and also groundwater flow pattern are the other factors controlling the chemistry of groundwater [35]. The piper diagram is a powerful tool with a convenient method for water type classification. The basis of its method is ionic composition of water samples [5].

This diagram helps to understand hydrochemical evolution of groundwater. Moreover, by plotting similar water samples together as a group, piper diagram shows their similarities and differences [36] [37].

Based on data collected from sampling wells in 2013, the piper diagram of water samples are drawn (Figure 11). According to this diagram and Table 6, sodium seems to be the dominant cation, while chloride has higher concentrations in comparison with other anions. In this basin the major ions dominance order are as follows: $\mathrm{Na}>\mathrm{Ca}>\mathrm{Mg}>\mathrm{K}$ and $\mathrm{Cl}>\mathrm{SO}_{4}>\mathrm{HCO}_{3}$ which means that the dominant water type is $\mathrm{Na}-\mathrm{Cl}$. This is mainly different from the routine type of fresh water in Iran $\left(\mathrm{Ca}-\mathrm{HCO}_{3}\right)$. Moreover, in all samples strong acids $(\mathrm{Cl}+$ $\left.\mathrm{SO}_{4}\right)$ outstrip weak acids $\left(\mathrm{HCO}_{3}+\mathrm{CO}_{3}\right)$.

According to Chebotarev, as groundwater flows through its path from the recharge zone to the discharge zone the order of major anions exists in bicarbonate, sulfate and chloride sequentially [13]. Accordingly, being in the vicinity of salt lake (discharge zone) is a reason for chloride domination in the groundwater type of this basin.

One of the good indicators to distinguish rock sources of the basin is

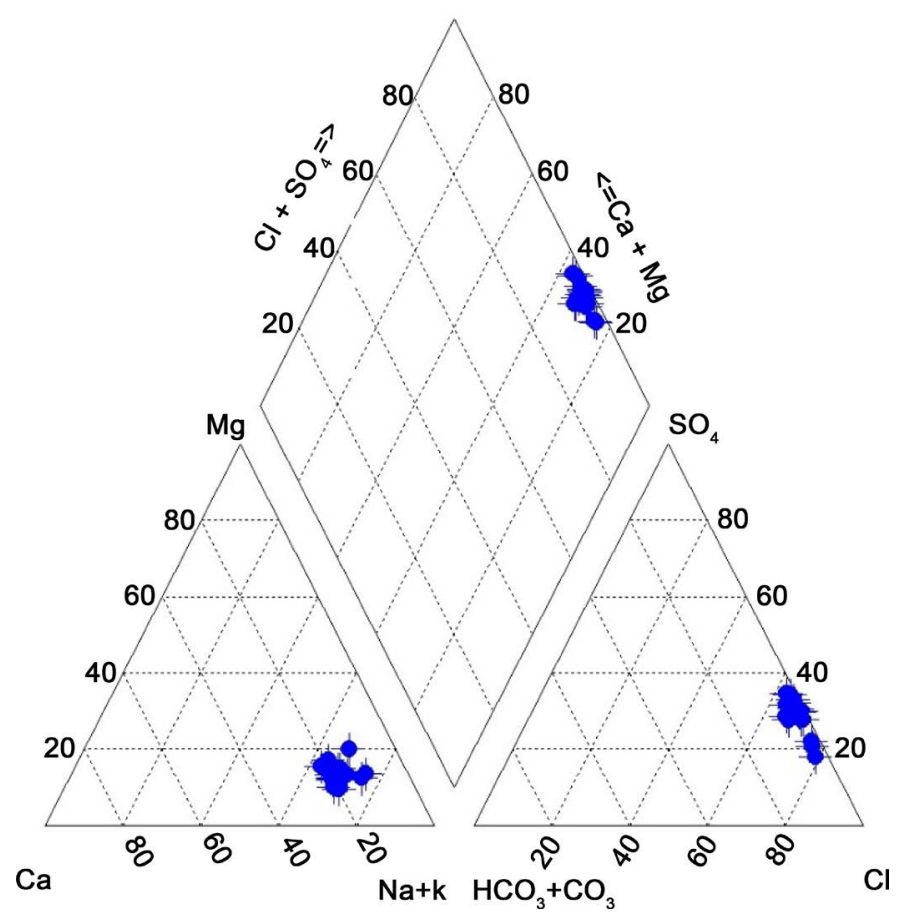

Figure 11. Piper diagram of 17 sampling wells. 
Table 6. Percentage of constituents in sampling wells.

\begin{tabular}{|c|c|c|c|c|c|c|c|c|c|}
\hline \multirow{2}{*}{$\begin{array}{c}\text { Sampling } \\
\text { No }\end{array}$} & \multicolumn{4}{|c|}{ Percentage of cations } & \multicolumn{3}{|c|}{ Percentage of anions } & \multirow{2}{*}{$\mathrm{Cl} / \mathrm{HCO}_{3}$} & \multirow{2}{*}{$\mathrm{Na} /(\mathrm{Na}+\mathrm{Cl})$} \\
\hline & $\mathrm{Ca} \%$ & $\mathrm{~K} \%$ & $\mathrm{Na} \%$ & $\mathrm{Mg} \%$ & $\left(\mathrm{HCO}_{3}+\mathrm{CO}_{3}\right) \%$ & $\mathrm{SO}_{4} \%$ & $\mathrm{Cl} \%$ & & \\
\hline W1 & 20.15 & 0.37 & 67.50 & 11.97 & 5.26 & 27.58 & 67.16 & 12.8 & 0.50 \\
\hline W2 & 20.03 & 0.34 & 67.33 & 12.30 & 3.95 & 31.43 & 64.62 & 16.4 & 0.51 \\
\hline W3 & 10.90 & 0.18 & 75.40 & 13.53 & 2.41 & 21.89 & 75.70 & 31.5 & 0.50 \\
\hline W4 & 21.54 & 0.23 & 62.85 & 15.38 & 2.06 & 27.63 & 70.31 & 34.1 & 0.49 \\
\hline W5 & 17.64 & 0.26 & 67.35 & 14.75 & 5.58 & 28.44 & 65.98 & 11.8 & 0.51 \\
\hline W6 & 19.80 & 0.31 & 70.41 & 9.48 & 3.17 & 17.96 & 78.87 & 24.9 & 0.49 \\
\hline W7 & 12.70 & 0.25 & 74.70 & 12.34 & 2.73 & 20.52 & 76.74 & 28.6 & 0.49 \\
\hline W8 & 16.88 & 0.26 & 68.05 & 14.81 & 2.41 & 30.72 & 66.86 & 28.1 & 0.50 \\
\hline W9 & 15.89 & 0.43 & 70.37 & 13.32 & 2.33 & 34.59 & 63.08 & 27.0 & 0.51 \\
\hline W10 & 12.00 & 0.23 & 67.85 & 19.93 & 1.59 & 32.08 & 66.33 & 41.8 & 0.51 \\
\hline W11 & 19.96 & 0.20 & 66.62 & 13.23 & 1.60 & 34.20 & 64.20 & 40.0 & 0.50 \\
\hline W12 & 20.94 & 0.32 & 68.74 & 9.99 & 1.80 & 29.56 & 68.64 & 38.1 & 0.50 \\
\hline W13 & 18.18 & 0.28 & 69.67 & 11.88 & 1.52 & 27.63 & 70.85 & 48.1 & 0.51 \\
\hline W14 & 19.84 & 0.25 & 67.72 & 12.19 & 1.50 & 32.81 & 65.69 & 44.8 & 0.49 \\
\hline W15 & 18.80 & 0.27 & 63.89 & 17.04 & 1.57 & 30.54 & 67.89 & 43.4 & 0.48 \\
\hline W16 & 18.33 & 0.14 & 68.65 & 12.88 & 1.38 & 29.74 & 68.88 & 51.0 & 0.48 \\
\hline W17 & 18.29 & 0.23 & 68.49 & 13.00 & 0.88 & 29.89 & 69.23 & 80.5 & 0.48 \\
\hline
\end{tabular}

Table 7. Sodium source deduction of sampling wells.

\begin{tabular}{ccc}
\hline $\mathrm{Na} /(\mathrm{Na}+\mathrm{Cl})$ & Conclusion & Number of samples \\
\hline$<0.5, \mathrm{TDS}>500$ & Reverse Softening, seawater & 7 \\
$<0.5,50<\mathrm{TDS}<500$ & Analysis Error & 0 \\
$<0.5, \mathrm{TDS}<50$ & Rainwater & 0 \\
$>0.5$ & Sodium source other than halite-albite, ion exchange & 0 \\
0.5 & Halite solution & 10 \\
\hline
\end{tabular}

sodium-chloride ratio [38]. Table 7 shows the possible contamination sources of water samples based on $\mathrm{Na} /(\mathrm{Na}+\mathrm{Cl})$ ratio in 2013. In this basin the aforementioned ratio were in the range of $0.48-0.51$ (Table 6). Based on Table 7, ten samples were contaminated by halite solution and 7 samples were contaminated by saltwater intrusion.

Domination of chloride ion in sea water on one hand and bicarbonate ion abundance in groundwater on the other hand, makes chloride-bicarbonate ratio a useful indicator to identify saltwater intrusion [39].

The ratios of $\mathrm{Cl} / \mathrm{HCO}_{3}$ in sampling wells in 2013 are shown in Table 6. Raghunath proposed ratio of $\mathrm{Cl} / \mathrm{HCO}_{3}=2.8$ as the threshold for saltwater intrusion [39]. According to ratios presented in Table 6 and the proposed threshold, all samples have higher ratio than the prescribed ratio which means they are all 


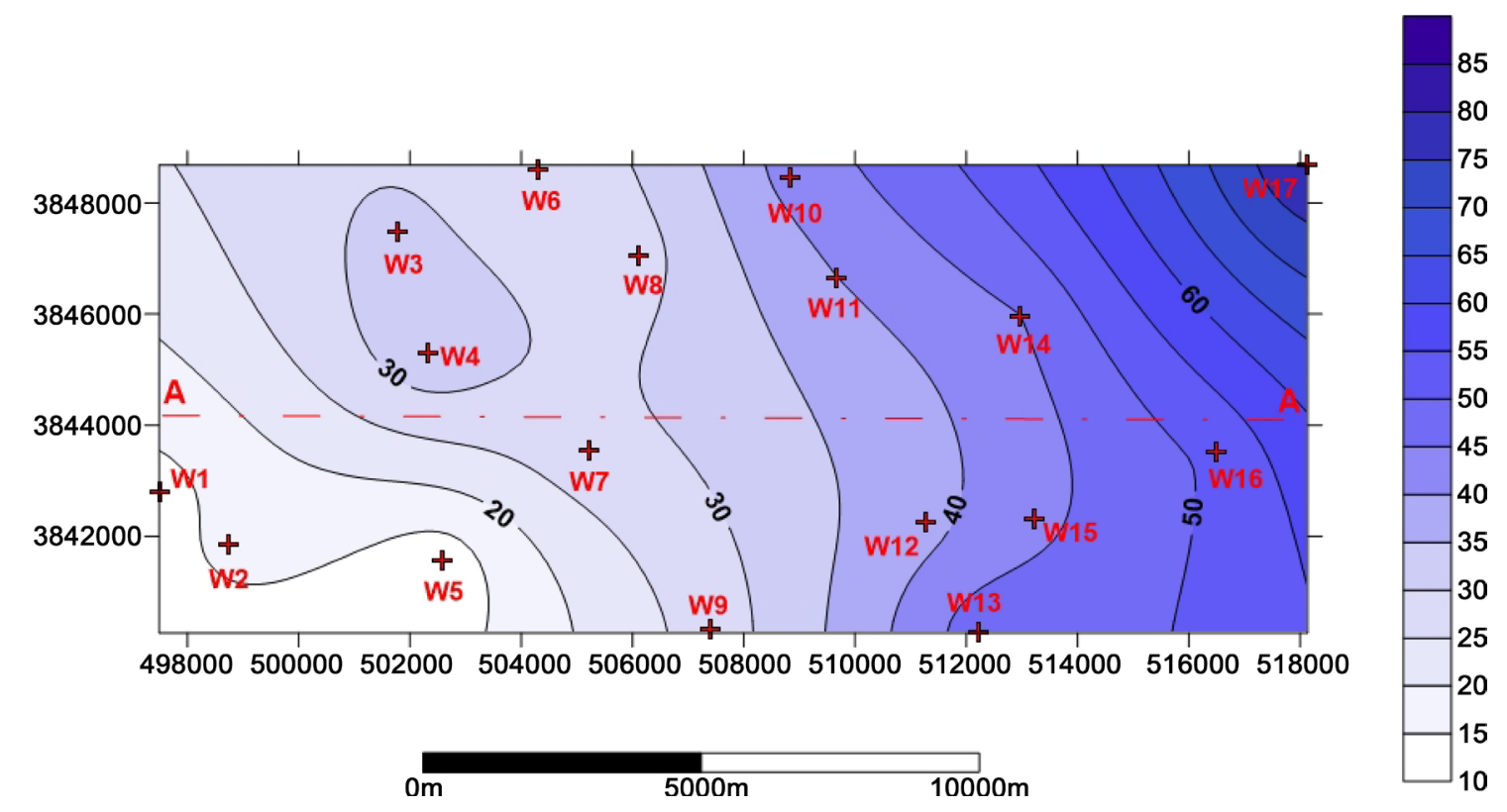

Figure 12. The distribution of chloride-bicarbonate ratio of sampling wells.

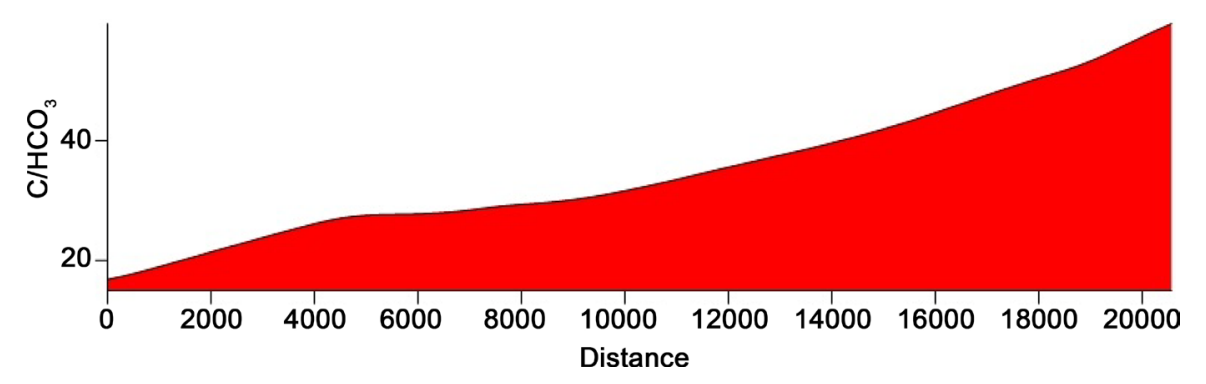

Figure 13. Section A-A.

contaminated by saltwater intrusion. This ratio is higher in eastern part of the ba$\sin$, near the Salt Lake. Figure 12 shows the distribution of chloride-bicarbonate ration in the study area and Section A-A (Figure 13) shows the increase of this ratio from the west to east part of basin, toward the Salt Lake.

Regarding water quality for agricultural use, Wilcox diagram, Sodium percentage and sodium adsorption ratio are considered.

The effect of the mineral dissolutions of water on both plants and soil should be taken into consideration in order to determine the suitability of groundwater for irrigation [40]. Salts change the osmotic procedure and cause restriction in uptake of water, and also contribute to metabolic reactions such as those caused by toxic constituent. These two phenomena impair the plant growth physically and chemically, respectively [41]. However, certain ions concentrations such as sodium and boron impacts on plants growth rather than the total salt concentration [16]. Sodium reacts with soil which results in low soil permeability, so it is an essential ion in classifying irrigation water. In this study following equation was used to calculate sodium percentage [29]:

$$
\mathrm{Na} \%=\frac{(\mathrm{Na}+\mathrm{K}) * 100}{(\mathrm{Na}+\mathrm{Ca}+\mathrm{Mg}+\mathrm{K})}
$$


Table 8. Irrigation quality of groundwater classification based on $\mathrm{Na} \%$.

\begin{tabular}{ccc}
\hline $\mathrm{Na} \%$ & Classification & Number of samples \\
\hline$<20$ & Excellent & 0 \\
$20-40$ & Good & 0 \\
$40-60$ & permissible & 0 \\
$60-80$ & Doubtful & 17 \\
$>80$ & Unsuitable & 0 \\
\hline
\end{tabular}

where the concentrations of the constituents are reported in meq/L.

Classification of water samples based on sodium percentage is shown in Table 8, which indicates that all of samples are in doubtful category.

To appraise the suitability of water for irrigation purpose Wilcox diagram is used. Vertical and horizontal axis of Wilcox diagram is sodium absorption ratio (SAR) and (EC), respectively. SAR specifies the threshold in which water participates in cation exchange. Substitution of $\mathrm{Na}$ with $\mathrm{Ca}$ and $\mathrm{Mg}$ makes the soil compact and impervious which is a hazard for plants growth. Soil compaction diminishes the air and water circulation in wet conditions and normally makes soil hard in dry condition [42] [43]. SAR was computed using the following equation:

$$
\mathrm{SAR}=\frac{\mathrm{Na}}{[(\mathrm{Ca}+\mathrm{Mg}) / 2]^{0.5}}
$$

where the concentrations are reported in meq/L.

Water with SAR value higher than 10, results in permeability issues in soil and ultimately destroys soil structure. Soils with damaged structure cannot bear heavy agricultural machinery loads. SAR range of 10 to 25 is slightly satisfactory for irrigation but only on well drained soils with low salinity. But SAR values higher than 25 are not acceptable under any condition [44].

The SAR and electrical conductivity values plotted on the Wilcox diagram indicate that all of the groundwater samples belong to C4S4 category (Figure 14).

Water classification in this diagram is presented in two letters, first letter which includes C1-C4, depicts water categories with raising salinity hazard and second letter which includes S1-S4, depicts water categories with raising peril of exchangeable sodium accumulation in irrigated soil. Water samples belonging to $\mathrm{C} 1 \mathrm{~S} 1$ and $\mathrm{C} 2 \mathrm{~S} 1$ categories, are considered as good quality water. Moderate water belongs to C1S2, C2S2, C3S2 and C3S1 categories. Water samples which fall in other categories are considered as inferior quality water [4].

These types of groundwater with very high salinity and sodium (C4S4) can be considered to have very poor quality, which can be used only for few plants with high salt tolerance.

\section{Conclusions}

Quality and quantity of groundwater in Sharif Abad aquifer located in Iran Central Kavir desert were studied in this paper. Quantitative analysis results showed 


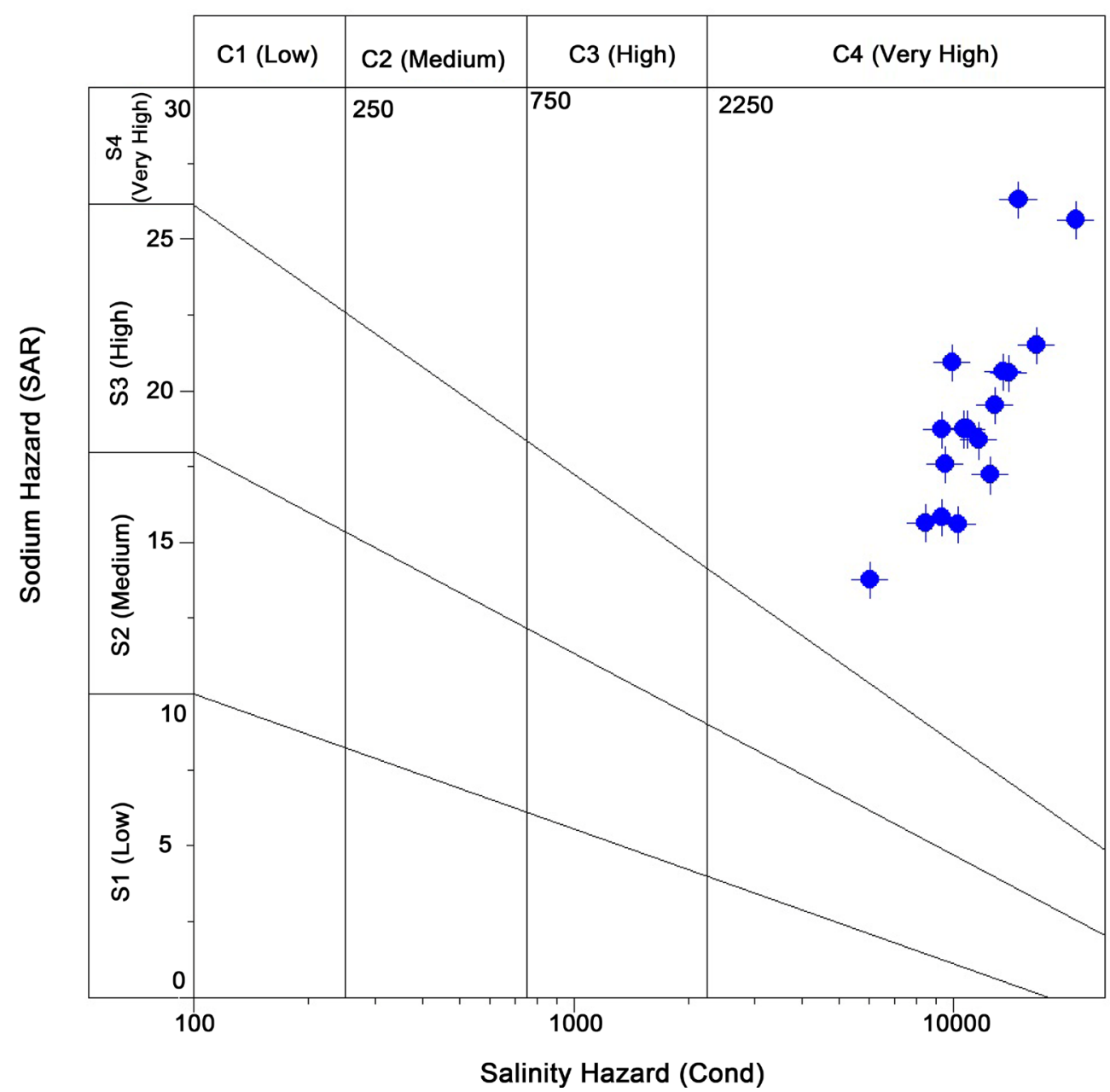

Figure 14. Wilcox diagram of 17 sampling wells.

that mean water table has decreased about $17 \mathrm{~m}$ between 1993 and 2013, indicating an average water table decline of $0.896 \mathrm{~m} /$ year. The comparison of results from different ions concentration measurement of samples collected from 17 sampling wells in 2013 with WHO standards showed that groundwater of this area was not suitable for drinking. The Suitability of groundwater for irrigation purpose was evaluated using Wilcox diagram. The results indicate that all the water samples in 2013 belong to C4S4 category, which means they are not suitable for irrigation, either. Spatial distribution of TDS, $\mathrm{Cl}$ and EC demonstrate an increasing pattern toward the Salt Lake (Eastward). Closed contour in EC, TDS and $\mathrm{Cl}$ spatial distribution diagram in the west and north parts of the area with higher concentration than surrounding ones may be the sign of salt domes and/or very high groundwater pumping which has led to the coming up of deeper saline and connate water. According to piper diagram and AquaChem analysis result, the dominant groundwater type in this area is $\mathrm{Na}-\mathrm{Cl}$ which is mainly different from the routine type of fresh water in Iran $\left(\mathrm{Ca}-\mathrm{HCO}_{3}\right)$. The dominant cation and anion of groundwater are $\mathrm{Na}$ and $\mathrm{Cl}$, respectively.

The quality of groundwater in this basin was impaired by saltwater intrusion from the Salt Lake and the interaction between groundwater and salt domes. 
According to the ratio of $\mathrm{Cl} / \mathrm{HCO}_{3}, 100 \%$ of the samples are contaminated by saltwater intrusion. Additionally, according to $\mathrm{Na} /(\mathrm{Na}+\mathrm{Cl})$ ratio almost $40 \%$ of samples were contaminated by Halite solution indicating the presence of salt domes in this area. Over pumping of groundwater, especially for irrigation purposes, has disturbed the hydraulic and hydrochemical equilibrium of the groundwater.

Since the principal use of pumped groundwater in this area is for agriculture, changing the irrigation method from traditional techniques to mechanized and also cultivating plants with low water demands and high resistance against salinity are suggested. Controlling extraction from aquifer by developing pumping restriction area and consisting the water share from dams in upstream would be effective policies to save the basin.

\section{References}

[1] Pazand, K. and Javanshir, A.R. (2014) Geochemistry and Water Quality Assessment of Groundwater around Mohammad Abad Area, Bam District, SE Iran. Water Quality, Exposure, and Health, 6, 225-231. https://doi.org/10.1007/s12403-014-0131-9

[2] Nabi Bidhendi, G.R., Karbassi, A.R., Nasrabadi, T. and Hoveidi, H. (2007) Influence of Copper Mine on Surface Water Quality. International Journal of Environmental Science and Technology, 4, 85-91. https://doi.org/10.1007/BF03325965

[3] Kumar, P.S. (2014) Evolution of Groundwater Chemistry in and around Vaniyambadi Industrial Area. Differentiating the Natural and Anthropogenic Sources of Contamination. Chemie der Erde/ Geochemistry, 74, 641-651.

[4] Nag, S.K. (2014) Evaluation of Hydrochemical Parameters and Quality Assessment of the Groundwater in Gangajalghati Block, Bankura District, West Bengal, India. Arabian Journal for Science and Engineering, 39, 5715-5727. https://doi.org/10.1007/s13369-014-1141-4

[5] Aly, A.A., Al-Omran, A.M. and Alharby, M.M. (2015) The Water Quality Index and Hydrochemical Characterization of Groundwater Resources in Hafar Albatin, Saudi Arabia. Arabian Journal of Geosciences, 8, 4177-4190.

https://doi.org/10.1007/s12517-014-1463-2

[6] Krishna kumar, S., Logeshkumaran, A., Magesh, N.S., Godson, P.S. and Chandrasekar, N. (2015) Hydro-Geochemistry and Application of Water Quality Index (WQI) for Groundwater Quality Assessment, Anna Nagar, Part of Chennai City, Tamil Nadu, India. Applied Water Science, 5, 335-343.

https://doi.org/10.1007/s13201-014-0196-4

[7] Psychoyou, M., Mimides, T., Rizos, S. and Sgoubopoulou, A. (2007) Groundwater Hydrochemistry at Balkan Coastal Plains-The Case of Marathon of Attica, Greece. Desalination, 213, 230-237.

[8] Yidana, S.M., Banoeng-Yakubo, B. and Akabzaa, T.M. (2010) Analysis of Groundwater Quality Using Multivariate and Spatial Analyses in the Keta Basin, Ghana. Journal of African Earth Sciences, 58, 220-234.

[9] Stamatis, G., Alexakis, D., Gamvroula, D. and Migiros, G. (2011) Groundwater Quality Assessment in Oropos-Kalamos Basin, Attica, Greece. Environmental Earth Sciences, 64, 973-988. https://doi.org/10.1007/s12665-011-0914-2

[10] Kshetrimayum, K.S. and Bajpai, V.N. (2012) Assessment of Groundwater Quality for Irrigation Use and Evolution of Hydrochemical Facies in the Markanda River 
Basin, Northwestern India. Journal of the Geological Society of India, 79, 189-198. https://doi.org/10.1007/s12665-011-0914-2

[11] Al-Ahmadi, M.E. (2013) Hydrochemical Characterization of Groundwater in Wadi Sayyah, Western Saudi Arabia. Applied Water Science, 3, 721-732. https://doi.org/10.1007/s13201-013-0118-x

[12] Clesceri, L.S., Greenberg, A.E. and Eaton, A.D. (1998) Standard Methods for the Examination of Water and Wastewater. 20th Edition, American Public Health Association, Washington DC.

[13] Chebotarev, I.I. (1955) Metamorphism of Natural Water in the Crust of Weathering, Geochim. Geochimica et Cosmochimica Acta, 8, 22-48, 137-170, 198-212.

[14] Baghvand, A., Nasrabadi, T., Bidhendi, G.N., Vosoogh, A., Karbassi, A. and Mehrdadi, N. (2010) Groundwater Quality Degradation of an Aquifer in Iran Central Desert. Desalination, 260, 264-275.

[15] WHO (2004) Guidelines for Drinking Water Quality. Vol. 1, Recommendations. 3rd Edition, WHO, Geneva.

[16] Kata, M., Mohan, R. and Krishna, K. (2015) Retracted Article. Hydrogeochemistry and Quality Assessment of Groundwater around Chromite-Mineralized Areas in India. Environmental Earth Sciences, 74, 6591. https://doi.org/10.1007/s12665-014-3479-z

[17] EPA (2012) Conductivity. US Environmental Protection Agency. http://water.epa.gov/type/rsl/monitoring/vms59.cfm

[18] Bauder, T.A., Waskom, R.M., Sutherland, P.L. and Davis, J.G. (2014) Irrigation Water Quality Criteria. Fact Sheet No. 0.506.

[19] Appelo, C.A.J. and Postma, D. (1996) Geochemistry, Groundwater and Pollution. Balkema, Rotterdam.

[20] Négrel, P. and Roy, S. (1998) Chemistry of Rainwater in the Massif Central (France). A Strontium Isotope and Major Element Study. Applied Geochemistry, 13, 941-952.

[21] Böhlke, J. and Horan, M. (2000) Strontium Isotope Geochemistry of Groundwaters and Streams Affected by Agriculture, Locust Grove, MD. Applied Geochemistry, 15, 599-609.

[22] Edmunds, W.M., Shand, P., Hart, P. and Ward, R.S. (2003) The Natural (Baseline) Quality of Groundwater. A UK Pilot Study. Science of the Total Environment, 310, 25-35.

[23] Valdes, D., Dupont, J., Laignel, B., Ogier, S., Leboulanger, T. and Mahler, B.J. (2007) A Spatial Analysis of Structural Controls on Karst Groundwater Geochemistry at a Regional Scale. Journal of Hydrology, 340, 244-255.

[24] Sarath Prasanth, S.V., Magesh, N.S., Jitheshlal, K.V., Chandrasekar, N. and Gangadhar, K. (2012) Evaluation of Groundwater Quality and Its Suitability for Drinking and Agricultural Use in the Coastal Stretch of Alappuzha District, Kerala, India. Applied Water Science, 2, 165-175. https://doi.org/10.1007/s13201-012-0042-5

[25] Pius, A., Jerome, C. and Sharma, N. (2012) Evaluation of Groundwater Quality in and around Peenya Industrial Area of Bangalore, South India Using GIS Techniques. Environmental Monitoring and Assessment, 184, 4067-4077.

https://doi.org/10.1007/s10661-011-2244-y

[26] Kapil, N. and Bhattacharyya, K.G. (2008) Bimonthly Variation of Wetland Water Quality: A Case Study with Deepor Beel, Assam, India. Proceedings of 16 th National Symposium on Environment, Haryana, 166-170. 
[27] Sajil Kumar, P.J., Elango, L. and James, E.J. (2014) Assessment of Hydrochemistry and Groundwater Quality in the Coastal Area of South Chennai, India. Arabian Journal of Geosciences, 7, 2641-2653. https://doi.org/10.1007/s12517-013-0940-3

[28] EPA (2012) Total Solids. US Environmental Protection Agency. http://water.epa.gov/type/rsl/monitoring/vms58.cfm

[29] Arumugam, K. and Elangovan, K. (2009) Hydrochemical Characteristics and Groundwater Quality Assessment in Tirupur Region, Coimbatore District, Tamil Nadu, India. Environmental Geology, 58, 1509-1520. https://doi.org/10.1007/s00254-008-1652-y

[30] USGS (2014) Water Hardness and Alkalinity. http://water.usgs.gov/owq/hardness-alkalinity.html

[31] Ramesh, K. and Elango, L. (2006) Groundwater Quality Assessment in Tondiar Basin. International Journal of Environment and Pollution, 26, 497-504.

[32] Subramani, T., Elango, L. and Damodarasamy, S.R. (2005) Groundwater Quality and Its Suitability for Drinking and Agricultural Use in Chithar River Basin, Tamil Nadu, India. Environmental Geology, 47, 1099-1110. https://doi.org/10.1007/s00254-005-1243-0

[33] EPA (2003) Drinking Water Advisory: Consumer Acceptability Advice and Health Effects Analysis on Sodium. http://www.epa.gov/safewater/ccl/pdf/sodium.pdf

[34] EPA (2003) Drinking Water Advisory: Consumer Acceptability Advice and Health Effects Analysis on Sulfate. http://www.epa.gov/safewater/ccl/pdf/sulfate.pdf

[35] Domenico, P.A. (1972) Concepts and Models in Groundwater Hydrology. McGrawHill Book Co., New York.

[36] Piper, A.M. (1944) A Graphic Procedure in the Geochemical Interpretation of Water-Analyses. Eos, Transactions American Geophysical Union, 25, 914. https://doi.org/10.1029/TR025i006p00914

[37] Todd, D.K. (2001) Groundwater Hydrology. Wiley, 280-281.

[38] Hounslow, A. (1995) Water Quality Data. In: Hounslow, A.W., Ed., Analysis and Interpretation, Lewis Publishers, Boca Raton, London.

[39] Raghunath, H.M. (1990) Groundwater. Wiley Eastern Limited, New Delhi.

[40] Rouabhia, A., Fehdi, C., Baali, F., Djabri, L. and Rouabhi, R. (2009) Impact of Human Activities on Quality and Geochemistry of Groundwater in the Merdja Area, Tebessa, Algeria. Environmental Geology, 56, 1259-1268. https://doi.org/10.1007/s00254-008-1225-0

[41] Todd, D.K. (1980) Groundwater Hydrology. 2nd Edition, Wiley, New York.

[42] Collins, R. and Jenkins, A. (1996) The Impact of Agricultural Land Use on Stream Chemistry in the Middle Hills of the Himalayas, Nepal. Journal of Hydrology, 185, 71-86.

[43] Saleh, A., Al-Ruwaih, F. and Shehata, M. (1999) Hydrogeochemical Processes Operating within the Main Aquifers of Kuwait. Journal of Arid Environments, 42, 195 209. https://doi.org/10.1006/jare.1999.0511

[44] Yidana, S.M. (2010) Groundwater Classification Using Multivariate Statistical Methods. Birimian Basin, Ghana. Journal of Environmental Engineering, 136, 1379 1388. https://doi.org/10.1061/(ASCE)EE.1943-7870.0000291 
Submit or recommend next manuscript to SCIRP and we will provide best service for you:

Accepting pre-submission inquiries through Email, Facebook, LinkedIn, Twitter, etc. A wide selection of journals (inclusive of 9 subjects, more than 200 journals)

Providing 24-hour high-quality service

User-friendly online submission system

Fair and swift peer-review system

Efficient typesetting and proofreading procedure

Display of the result of downloads and visits, as well as the number of cited articles Maximum dissemination of your research work

Submit your manuscript at: http://papersubmission.scirp.org/

Or contact wjet@scirp.org 